\title{
CRACKING AND DUCTILITY BEHAVIOUR OF CONCRETE BEAMS WITH PARTIAL REPLACEMENT OF COARSE AGGREGATES BY CINDER
}

\author{
Komari Sapthagiri' ${ }^{1}$ P Poornima ${ }^{2}$ \\ ${ }^{I}$ PG Student, Department of Structural Engineering, Sree Rama Engineering College, Rami Reddy Nagar, Tirupati, \\ Andhra Pradesh, India \\ ${ }^{2}$ Assistant Professor, Department of Structural Engineering, Shree Rama Educational Society Group of Institution, \\ Karkambadi, Tirupati, India
}

\begin{abstract}
Fast mechanical development, Environmental contamination, Scarcity of common assets, Economic outline of auxiliary components, Adoptability and reasonableness of new materials, Disposal issues, Cost powerful ventures, Usage of numerous modern squanders for use in bond solid applications have started the present examination. The measure of residue misuses is completely far reaching in India for use as an aggregate in bond. Fiery remains is conveyed in the midst of bursting of coal in various organizations. It is the material sintered at high temperatures. There are no terrible chemicals in residue. Squashed powder aggregate is a material especially proposed for the building worked in hot environments. The objectives of this review are to demonstrate the results of test study and examination on the lead and the nature of regular quality reinforced strong columns (NSC) and sustained strong bars with fiery remains adds up to and interfaces their results. Trial mixes were made to achieve a true blue mix for the strong of M40 assessment with proper workability to cast the bars. With the correct mix degree achieved, columns were tossed, estimations of each being $2800 \mathrm{~mm} \times 100 \mathrm{~mm} \times 145 \mathrm{~mm}$. The support of the poles contrasted from $0.84 \%$, $1.31 \%$ and $1.88 \%$. The bars were cured for 28 days. Taking after 28 days, every one of the bars were striven for flexure under two point stacking in a stacking packaging of 50tonnes farthest point. The store was associated by strategy for al00kN water driven jack, through a steel I-zone, supported on two steel rollers. The outcome acquired was then plotted as charts. The trial results are contrasted and IS 456:2000 arrangements. The systematic work included the count of redirections of test shafts utilizing the techniques as of now accessible as a part of the writing.Likewise, the outline arrangements contained in the American Concrete Institute Building Code ACI 318-2010, British Code BS 8110 and Euro Code EN 1992 are utilized to compute the quality of the considerable number of shafts.
\end{abstract}

Keywords: Cinder, Coarse Aggregate, Compressive Strength, Ductility, Ultimate Loads, Working Loads.

\section{INTRODUCTION}

The improvement business has been one of the top most divisions creating well-ordered with time. The building materials are gotten in immense sums and the more prepared structures are being pulverized to ground zero.

The enthusiasm for building materials has been always rising with the growing prerequisite for cabin both in rural and urban extents. The advancement business depends vivaciously on conventional materials, for instance, bond, shake and sand for the production of concrete. The high and extending cost of these materials with the expanding requirement for lodging both in rustic and urban ranges.

There rises the necessity for planning thought about the use of less costly and locally open materials to address longed for issue, update self-efficiency, and prompt to a general diminishment being developed cost for achievable headway. It has, thusly; get the chance to be critical to completely consider this issue really and to give some viable response for make the alternative materials open to deal with the cabin issue. In the start of the constrain time industry, coal burning items (CCPs) were thought to be a waste material. The properties of these materials were not focused on or surveyed really and about most of the coal start things were range filled. Over the traverse of time, the Cementitious and Pozzolanic properties of fly cinder were seen and focused on by a couple people and associations. The things were attempted to grasp their physical properties, substance properties and suitability as an advancement material. In the midst of the latest couple of decades these "waste" materials have seen a change to the status of "by-things" and all the more starting late "things" that are searched for improvement and diverse applications. In the midst of the past many years, period of force through various coal blazing strategies has created to oblige extended people and related present day and business change in the United States and distinctive parts of the world. These coal start frames surrender stores that are suggested as CCPs. The fundamental CCPs were called sediment and were encircled from seething bunch coal on lattices in stoker warmers. These fiery remains were from time to time used as road shake and once in a while as a lightweight aggregate in 
gathering block work "ash" squares. Residue is a pyroclastic, uncemented material and are extrusive volcanic rocks. They resemble pumice, having bubble-like pits, called vesicles measuring no less than 2.0 millimeters in no short of what one estimation. It has evident specific gravity some place around 1.0 and 2.0. Consistent fiery remains are red or dull in shading. Contain different gas bubbles "hardened" into spot as magma impacted into the air and a short time later cooled quickly. The measure of fiery debris waste is altogether considerable in India for use as an aggregate in bond. Residue is made in the midst of the bursting of coal in various business wanders. It is material sintered at high temperatures. There are no risky chemicals in cinder. Crushed fiery remains aggregate is a material especially proposed for the structures worked in hot airs. This Chapter shows the establishment to the prerequisites for the change of concrete with supplanted aggregates and the usage of ash as aggregate in bond. The available dispersed written work on residue add up to concrete is furthermore immediately examined.

\section{OBJECTIVE OF THE STUDY}

The present investigation can be extended to beams with many more percentages of replacement of coarse aggregates with cinder. An extensive research work has to be carried out to further study the effects of variation in tensile reinforcement with a wide range of percentage of tensile reinforcement. Investigation can also be extended to study the behaviour of doubly reinforced beams with coarse aggregates partially replaced by cinder. There is a scope for improving the codal provisions for the deflection determination of beams since; most of the codes do not predict the deflections of the beams with a reasonable accuracy. Extensive research has to be carried out on various higher concrete grades.

\section{EXPERIMENTAL PROGRAMME}

\subsection{Cement}

Ordinary Portland cement conforming to the specifications of IS: 12269-1987 was used. The cement was Ultra tech -53 Grade OPC. The chemical compositions of cement are presented in

Table: 1 Properties of Cement

\begin{tabular}{|c|c|c|}
\hline S.NO & PROPERTY & VALUES \\
\hline 1 & Specific Gravity & 3.15 \\
\hline 2 & Normal Consistency & $31 \%$ \\
\hline 3 & $\begin{array}{l}\text { Setting Time } \\
\text { a) Initial Setting time } \\
\text { b) Final setting time }\end{array}$ & $\begin{array}{l}45 \text { minutes } \\
7 \text { hours }\end{array}$ \\
\hline
\end{tabular}

\subsection{Fine Aggregate (FA)}

For the casting, locally available river-sand, free from silt and organic matters was procured and used. The particle size of fine aggregate used in this study was such a way that it passed through $4.75 \mathrm{~mm}$ sieve conforming to zone II of IS: 383-1970. The specific gravity of FA used was 2 .

\subsection{Coarse Aggregate (CA)}

Coarse aggregate used for the experiments was locally available crushed granite aggregate passing through $12.5 \mathrm{~mm}$ and retaining on $4.75 \mathrm{~mm}$ for all of the mixes. The aggregates used were conforming to IS: 383-1970. The specific gravity of CA used was 2.74 . And along with natural aggregates, Cinders were used, which were crushed down to pass through $20 \mathrm{~mm} \&$ retain on $4.75 \mathrm{~mm}$ sieves. The specific gravity of cinder used was 2.24 .

\subsection{Water}

Potable water free from injurious salts was used for both mixing and curing.

\subsection{The Mix Proportion of Normal Strength Concrete (NSC)}

The final mix proportions for M40 grade normal strength concrete is shown in Table 2:

Table 2: Mix Proportions for M40

\begin{tabular}{|l|l|}
\hline Cement & $492.9 \mathrm{~kg} / \mathrm{m}^{3}$ \\
\hline Coarse aggregate & $1099.12 \mathrm{~kg} / \mathrm{m}^{3}$ \\
\hline Fine aggregate & $673.65 \mathrm{~kg} / \mathrm{m}^{3}$ \\
\hline Water & $197.16 \mathrm{lit} / \mathrm{m}^{3}$ \\
\hline
\end{tabular}

The final mix proportions for various replacements of coarse aggregate are tabulated below in Table 3:

Table 3: Final Normal concrete mix proportions (M40)

\begin{tabular}{|l|l|l|l|}
\hline MIX No. & $\begin{array}{l}\text { CINDER } \\
\text { REPLACEME } \\
\text { NT\% }\end{array}$ & $\begin{array}{l}\text { NCA } \\
\text { Kgs }\end{array}$ & $\begin{array}{l}\text { CINDER } \\
\text { kgs }\end{array}$ \\
\hline NSC MIX 1 & 0 & 1098.04 & - \\
\hline NSC MIX 2 & 30 & 768.63 & 329.41 \\
\hline NSC MIX 3 & 50 & 549.02 & 549.02 \\
\hline NSC MIX 4 & 75 & 274.51 & 823.53 \\
\hline
\end{tabular}

\subsection{Test Specimens}

Accordingly, dimensions of the beam elements are explained below:

Overall Length $=2800 \mathrm{~mm}$,

Effective Length $=2400 \mathrm{~mm}$

Overall Depth $=145 \mathrm{~mm}$,

Breadth $=100 \mathrm{~mm}$,

Clear cover $=20 \mathrm{~mm}$, An "Effective Length by Overall Depth" ratio close to 15 considered.

IS 456:2000 guidelines regarding the minimum and the maximum reinforcement were used to obtain a practical 
range of the steel ratios which is permissible also. The maximum reinforcement in a beam according to the IS codes is to be kept within $4 \%$ of the cross sectional area. The percentage of reinforcements adopted were $0.84 \%, 1.31 \%$ \& $1.88 \%$ of the cross sectional area of the beam. Table-4below shows the details of the reinforcement used for the beams.

Table 4: Reinforcement calculations

\begin{tabular}{|l|l|l|l|}
\hline $\begin{array}{l}\text { Beam } \\
\text { no. }\end{array}$ & Reinforcement & $\begin{array}{c}\mathbf{A}_{\text {St)provm }} \\
\mathbf{2}\end{array}$ & $\begin{array}{l}\text { Ast)prov } \\
(\mathbf{\%})\end{array}$ \\
\hline 1 & $8 \mathrm{~mm}$ dia-2 nos & 100.53 & 0.84 \\
\hline 2 & $10 \mathrm{~mm}$ dia-2 nos & 157.08 & 1.31 \\
\hline 3 & $12 \mathrm{~mm}$ dia-2 nos & 226.19 & 1.88 \\
\hline
\end{tabular}

As the main aim of the present study is to investigate the flexural behaviour of RC beam elements, there should not be any other possibilities of failure occurrence rather than flexural failure. Consequently, beams should be designed for shear such a way that even under the ultimate moment carrying capacity shear failure doesn't happen.Percentages of reinforcement are carried out and the results are tabulated in the Table 5:

Table 5: Selection of Beam reinforcementThe detailing of reinforcements and other required dimensions of the beams

\begin{tabular}{|c|c|c|}
\hline \begin{tabular}{|lr}
$\%$ & stee \\
provided
\end{tabular} & $\begin{array}{l}A_{\text {Stprovided }} \\
\text { mm }^{2}\end{array}$ & $\begin{array}{l}\text { Reinforcement } \\
\text { details }\end{array}$ \\
\hline 0.84 & 100.53 & 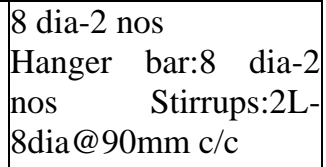 \\
\hline 1.31 & 157.08 & $\begin{array}{|ll|}10 \text { dia-2 } & \text { nos } \\
\text { Hanger } & \text { bar:8 dia-2 } \\
\text { nos } & \text { Stirrups:2L- } \\
\text { 8dia@90mm c/c }\end{array}$ \\
\hline 1.88 & 226.19 & \begin{tabular}{|l|l|}
2 dia-2 & nos \\
Hanger bar:8 dia-2 \\
nos $\quad$ Stirrups:2L- \\
8dia@90mm c/c
\end{tabular} \\
\hline
\end{tabular}
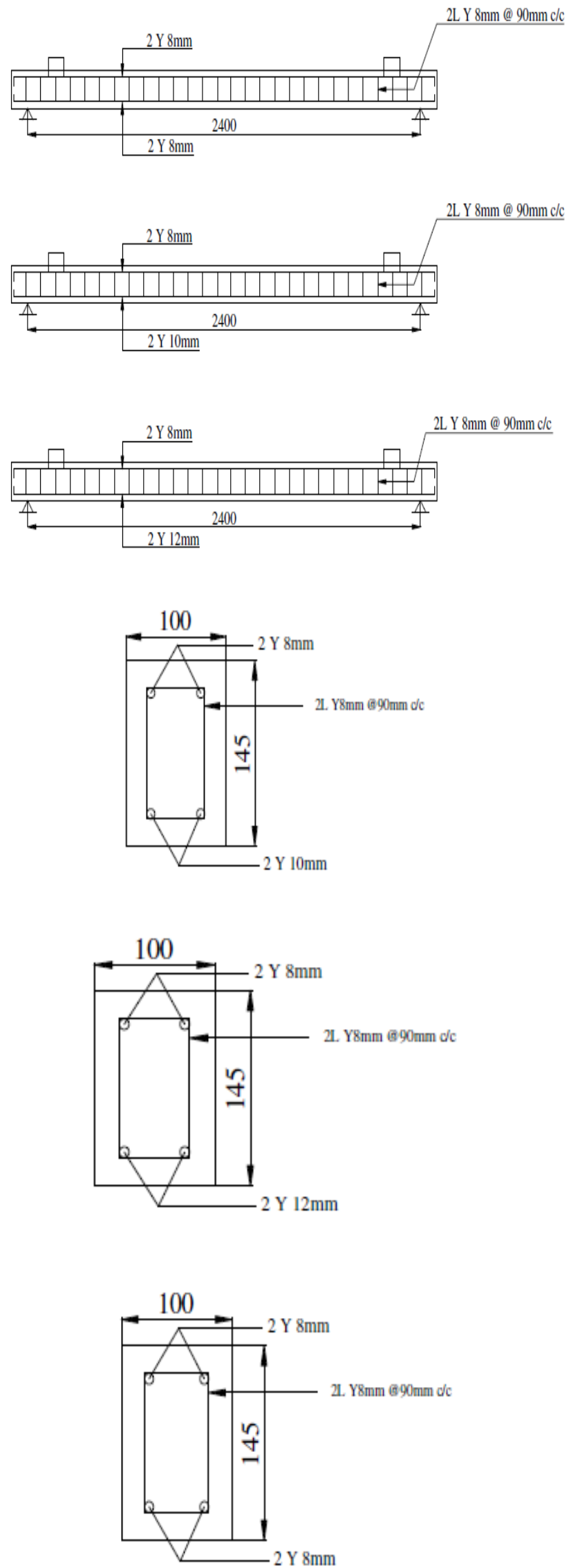

Fig 1: Details of the Beam Dimensions and Reinforcement Cages 


\section{RESULTS AND DISCUSSION}

\subsection{Compressive Strength \& Flexural Strength}

A number of trail mixes were conducted to obtain the mix proportion of M40 concrete. Compressive strength of the concrete influences the flexural behaviour of concrete beams. Therefore for each set of the beam specimen three cubes of 100X100X100 and three prisms of 75X75X450 were casted and tested. The results are tabulated in Table 6.the variation of compressive strength over the age (days) is presented in Figure 2.

Table 6: Flexural strength of Cinder Aggregate Concrete

\begin{tabular}{|l|l|l|l|}
\hline Beam & b mm & $\mathbf{d}$ mm & $\begin{array}{l}\text { Flexural Strength } \\
(\text { MPa })\end{array}$ \\
\hline N-0-1 & 100 & 120 & 5.61 \\
\hline N-0-2 & 100 & 120 & 4.81 \\
\hline N-0-3 & 100 & 120 & 5.61 \\
\hline N-30-1 & 100 & 120 & 4.67 \\
\hline N-30-2 & 100 & 120 & 5.45 \\
\hline N-30-3 & 100 & 120 & 5.45 \\
\hline N-50-1 & 100 & 120 & 6.09 \\
\hline N-50-2 & 100 & 120 & 4.57 \\
\hline N-50-3 & 100 & 120 & 5.33 \\
\hline N-75-1 & 100 & 120 & 5.38 \\
\hline N-75-2 & 100 & 120 & 4.61 \\
\hline N-75-3 & 100 & 120 & 6.15 \\
\hline
\end{tabular}

It has been observed from the graph that the 1day strength for $50 \%$ replacement of CA was higher compared to 0,30 \& $75 \%$. There is not much variation in the 3 and 7 day compressive strength. $0 \%$ replacement shows highest compressive strength followed by 30,50 and $75 \%$. It can also been observed that the mix with $50 \%$ replacement of $\mathrm{CA}$ reached the target compressive strength earlier followed by 0,75 and $30 \%$ subsequently.

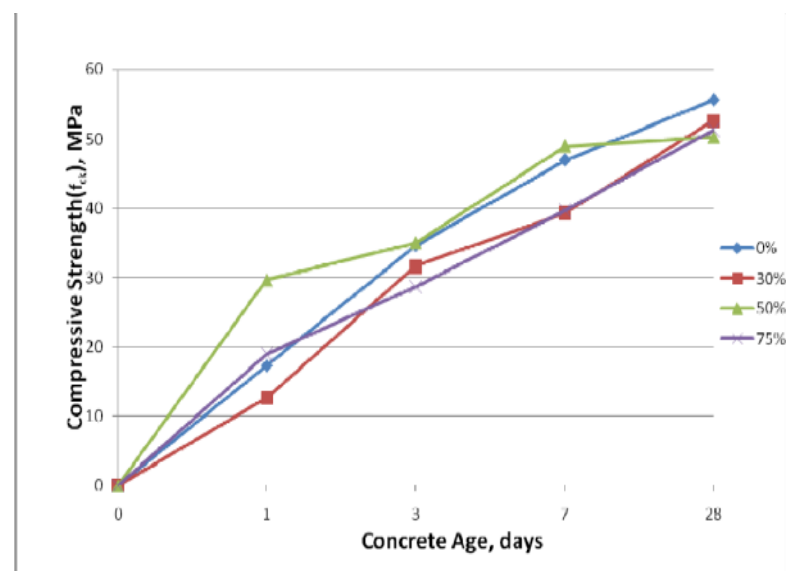

Fig 2: Age v/s Compressive strength curve for different replacements of coarse aggregate.

\subsection{Combined Load V/S Deflection Curve}

Combined load deflection behaviour based on the percentage replacement of cinder for various percentages of tensile reinforcement is presented below.

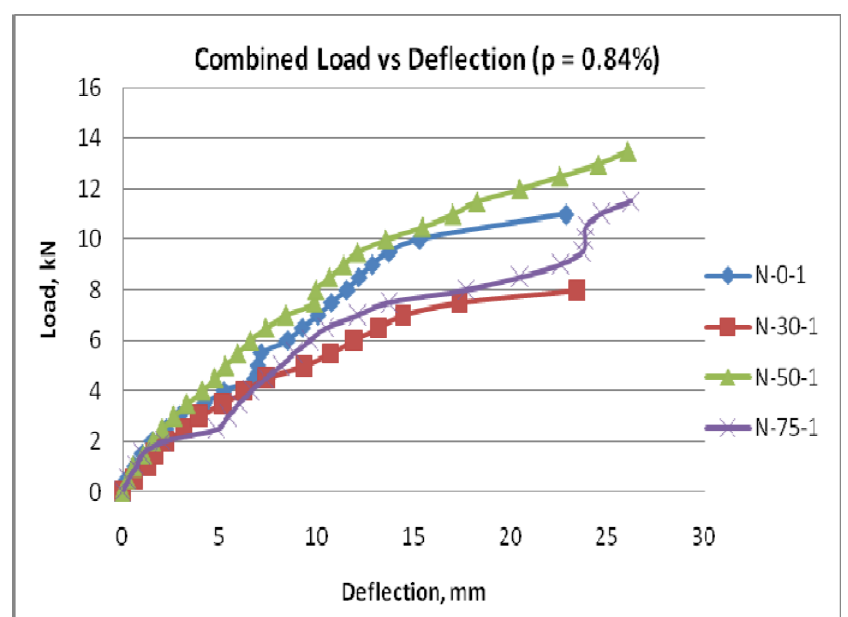

Fig 3: Combined Load v/s Deflection curve for $\mathrm{p}=0.84 \%$

The graph indicates that the load as well as the deflection is higher for beam with $50 \%$ replacement of coarse aggregate. The ultimate load of Beam N-30-1is the least compared to all the other percentages ofreplacement.

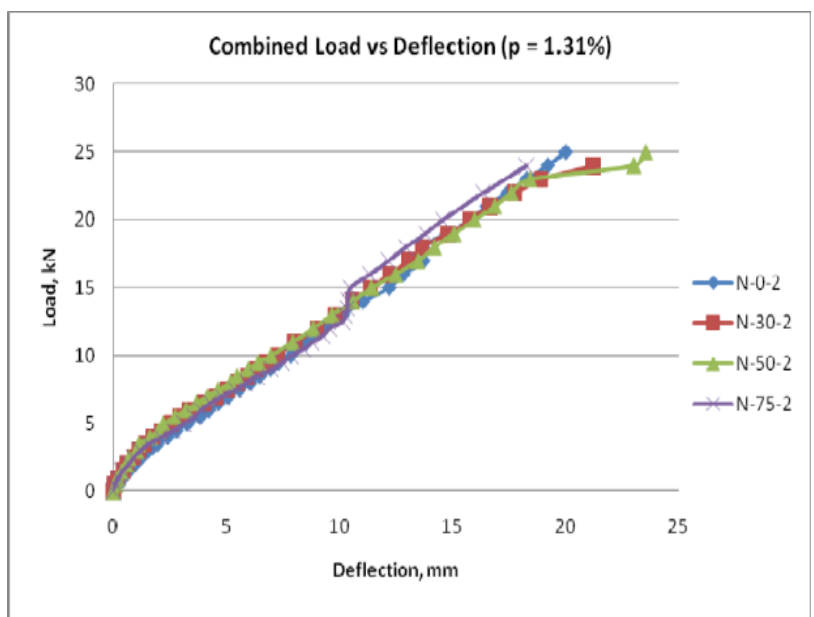

Fig 4: Combined Load v/s Deflection curve for $p=1.31 \%$

All the beams show linear variation towards the ultimate capacity. The variation in the deflection and load carrying capacity is very small in all the beams. But, in case of N$75-2$, at around $13 \mathrm{kN}$, there was a very small increase in deflection with the increase in load up to $15 \mathrm{kN}$, thereafter, the load v/s deflection curve shows same trend as other beams. The ultimate loads of all the beams are almost the same whereas the deflections very much, with beam N-50-2 having more deflection compared to others. 


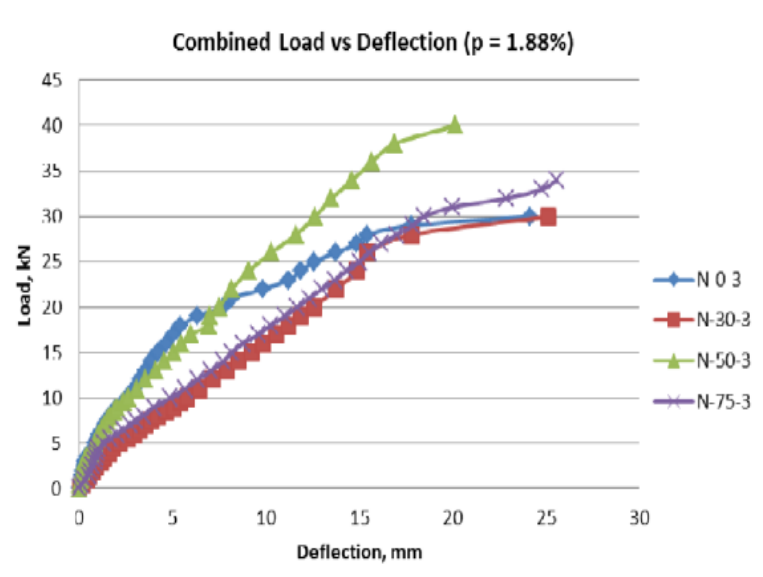

Fig 4.17: Combined Load v/s Deflection curve for $\mathrm{p}=$ $1.88 \%$

There is a considerable difference in the deflection and load carrying capacity of beam N-50-3 compared over the other three beams. The load deflection curve for $\mathrm{N}-0-3$ is steeper up to $20 \mathrm{kN}$. The load deflection curves for N-30-3 and N75-3 follow the same trend.

\subsection{Cracking and Ultimate Load}

The cracking and ultimate load along with the maximum deflection and crack width were recorded during the testing of each beam and the same is reported in the Table 7 .

Table 7: Cracking and Ultimate load of beams.

\begin{tabular}{|l|l|l|l|}
\hline Beam & $\begin{array}{l}\text { Pu } \\
\text { kN }\end{array}$ & $\begin{array}{l}\text { Crack width } \\
\mathbf{m m}\end{array}$ & $\begin{array}{l}\Delta \mathbf{m a x} \\
\mathbf{m m}\end{array}$ \\
\hline $\mathrm{N}-0-1$ & 11 & 0.04 & 22.86 \\
\hline $\mathrm{N}-0-2$ & 25 & 0.15 & 20.01 \\
\hline $\mathrm{N}-0-3$ & 30 & 0.08 & 24.12 \\
\hline $\mathrm{N}-30-1$ & 8 & 0.07 & 23.43 \\
\hline $\mathrm{N}-30-2$ & 24 & 0.07 & 21.25 \\
\hline $\mathrm{N}-30-3$ & 30 & 0.12 & 25.12 \\
\hline $\mathrm{N}-50-1$ & 13.5 & 0.05 & 26.07 \\
\hline $\mathrm{N}-50-2$ & 25 & 0.15 & 23.57 \\
\hline $\mathrm{N}-50-3$ & 40 & 0.04 & 20.13 \\
\hline $\mathrm{N}-75-1$ & 11.5 & 0.12 & 27.71 \\
\hline $\mathrm{N}-75-2$ & 24 & 0.1 & 18.29 \\
\hline $\mathrm{N}-75-3$ & 34 & 0.05 & 25.57 \\
\hline
\end{tabular}

It has been observed from the abovethat with the increase in percentage of tensile reinforcement, the ultimate load capacity increased. It is also evident that with the increase in tensile reinforcement ratio, there is an increase in the cracking load.

Table 8: Displacement Ductility of Beams.

\begin{tabular}{|l|l|l|l|l|l|l|}
\hline $\begin{array}{l}\text { BEAM } \\
\text { No. }\end{array}$ & $\begin{array}{l}\text { Fck, } \\
\mathrm{MPa}\end{array}$ & $\mathrm{p}, \%$ & fy, MPa & $\begin{array}{l}\Delta \mathrm{u}, \\
\mathrm{mm}\end{array}$ & $\Delta \mathrm{y}, \mathrm{mm}$ & $\mu \Delta$ \\
\hline $\mathrm{N}-0-1$ & 58 & 0.84 & 500 & 22.85 & 10.362 & 2.21 \\
\hline $\mathrm{N}-0-2$ & 54 & 1.31 & 500 & 20.01 & 10.630 & 1.88 \\
\hline
\end{tabular}

\begin{tabular}{|l|l|l|l|l|l|l|}
\hline $\mathrm{N}-0-3$ & 55 & 1.88 & 500 & 24.12 & 13.384 & 1.80 \\
\hline $\mathrm{N}-30-1$ & 60 & 0.84 & 500 & 23.42 & 9.421 & 2.49 \\
\hline $\mathrm{N}-30-2$ & 50 & 1.31 & 500 & 21.24 & 12.111 & 1.75 \\
\hline $\mathrm{N}-30-3$ & 48 & 1.88 & 500 & 25.12 & 15.184 & 1.65 \\
\hline $\mathrm{N}-50-1$ & 50 & 0.84 & 500 & 26.07 & 10.902 & 2.39 \\
\hline $\mathrm{N}-50-2$ & 43 & 1.31 & 500 & 23.56 & 11.951 & 1.97 \\
\hline $\mathrm{N}-50-3$ & 58 & 1.88 & 500 & 20.13 & 10.761 & 1.87 \\
\hline $\mathrm{N}-75-1$ & 58 & 0.84 & 500 & 27.71 & 11.240 & 2.47 \\
\hline $\mathrm{N}-75-2$ & 56 & 1.31 & 500 & 18.28 & 11.369 & 1.61 \\
\hline $\mathrm{N}-75-3$ & 40 & 1.88 & 500 & 25.57 & 16.002 & 1.60 \\
\hline
\end{tabular}

Table 9: Deflection of beams at working load using different codes

\begin{tabular}{|l|l|l|l|}
\hline Beam no. & $\begin{array}{l}\text { ACI 318-IS 456 } \\
\mathbf{2 0 1 0} \\
\mathbf{m m}\end{array}$ & $\begin{array}{l}\text { Experimental } \\
\text { Deflection } \\
(\mathbf{m m})\end{array}$ \\
\hline $\mathrm{N}-0-1$ & 8.70 & 7.44 & 10.28 \\
\hline $\mathrm{N}-0-2$ & 15.11 & 15.45 & 13.14 \\
\hline $\mathrm{N}-0-3$ & 13.94 & 14.54 & 7.69 \\
\hline $\mathrm{N}-30-1$ & 5.80 & 4.36 & 9.52 \\
\hline $\mathrm{N}-30-2$ & 14.65 & 14.98 & 12.21 \\
\hline $\mathrm{N}-30-3$ & 14.24 & 14.95 & 12.34 \\
\hline $\mathrm{N}-50-1$ & 11.24 & 10.37 & 11.62 \\
\hline $\mathrm{N}-50-2$ & 15.60 & 16.17 & 12.62 \\
\hline $\mathrm{N}-50-3$ & 18.49 & 19.70 & 10.47 \\
\hline $\mathrm{N}-75-1$ & 9.16 & 7.94 & 15.01 \\
\hline $\mathrm{N}-75-2$ & 14.42 & 14.64 & 12.10 \\
\hline $\mathrm{N}-75-3$ & 16.64 & 17.75 & 13.18 \\
\hline
\end{tabular}

\section{CONCLUSION}

The report presents information on Normal strength concrete with cinder aggregates. Cinder is used to replace natural aggregates in varying percentages. Various trial mixes were done to obtain M40 grade concrete .A total of twelve beams were cast with varying percentage of reinforcement and varying percentage of coarse aggregate replacement. Each beam was individually tested under two point loading and the results were compared with calculated values using various codes. The maximum crack width of $\mathrm{RC}$ beam at working load is not supposed to exceed $0.3 \mathrm{~mm}$ according to the code, and in the experiment it is observed that the width of crack is well within the limits. The crack width calculated at working load using different codes gives varying values, with ACI 3182010 giving the highest value and IS 456 the least. The ratios of experimental to calculated crack widths were computed and their average being $0.72,0.95$ and 0.92 with coefficient of variation of $0.47,0.46$ and or ACI, IS and BS codes respectively. It can be observed that IS code gives best mean of 0.95 and the difference in of co-efficient of variation is less between all the codes.The deflection ductility was computed as the ratio of deflection at ultimate load to that of yield load. The yield load was calculated using Bi-linear method. In the literature the ductility factor of less than 5 is considered to be suitable for concrete 
structures and elements. Therefore, the obtained results in the present study showed that all the specimens had a ductile behaviour. As expected it was found that the available deflectionductility index decreased as the longitudinal reinforcement ratio is increased.Also it is found that the ductility index of beams with $50 \%$ replacement of CA (N50-2 \& N-50-3) is higher compared to other beams.

\section{REFERENCES}

[1] Muyasser M Jomaa'h, Hosam A Daham, Saad M Rao, "Flexural Behavior of Lightweight Concrete Beams "European Journal of Scientific Research ISSN 1450- 216X Vol.58 No.4 (2011),pp.582-592

[2] Kamel K Alzboon and Khalid N '(2009),"Effect of Using Stone Cutting Waste on the Compression Strength and Slump Characteristics of Concrete", International Journal of Civil and Environmental Engineering , 1:4 2009.

[3] N Siva LingaRao, G VenkataRamana, V Bhaskar Desai \& B L P Swamy "Properties of Light Weight Aggregate Concrete with Cinder and Silicafume Admixture" International Journal of Earth Sciences and Engineering ISSN 0974-5904, Volume 04, No 06 SPL, October 2011, pp907-912

[4] Limit state design of reinforced concrete structures by B C Punmia, Ashok kumarjain, arunkumarjain.

[5] Bureau of Indian Standards "Plain and Reinforced Concrete Code of Practice", IS 456:2000.

[6] American Concrete Institute "Building Code Requirements for Structural Concrete and Commentary", ACI318-02,2010. 